\title{
Aceruloplasminemia Presenting with Cognitive Impairment
} Kognitif Bozukluk ile Başvuran Aseruloplazminemi Olgusu

Keywords: Aceruloplasminemia, cognitive impairment, iron accumulation

Anahtar Kelimeler: Aseruloplazminemi, kognitif yıkım, demir birikimi

\section{Dear Editor,}

A 66-year-old female admitted to neurology clinic with forgetfulness, which she had had for 2 years. She was hospitalized for further investigation because cranial magnetic resonance imaging (MRI) showed bilateral hypointense signal changes in the basal ganglia and thalamus, which suggested accumulation of heavy metals. Neurologic examination was normal except mild dysarthria and impaired tandem walk. There were no remarkable features in her past and family history. A severe difficulty in ability to sustain attention, decline in verbal fluency, and impairment in all processes of memory were found in the cognitive assessment. Abdominal MRI showed a decrease in the signal of liver parenchyma due to accumulation of metal (Figure 1,2). Liver biopsy showed ballooning degeneration of hepatocytes and an accumulation of iron was observed in hepatocytes and Kupffer cells in the form of small and large granules. Examination of the fundus and anterior segment revealed normal findings. Serum iron was low, serum ferritin was high, and transferrin saturation was low. Also, the serum level of ceruloplasmin (CP) was $<2.1 \mathrm{mg} / \mathrm{L}$, fasting blood glucose was $148 \mathrm{mg} / \mathrm{dL}$, and microcytic anemia was found. After consulting with hematology, chelation therapy was initiated due to the disturbance of iron metabolism. Blood glucose levels were high at follow-up and an oral antidiabetic agent was initiated. Copper was not detected in the serum or urine of the patient. Oral zinc treatment $(200 \mathrm{mg} / \mathrm{d})$ was initiated.
Brain MRI showed bilateral signal changes in the white matter of the cerebellum, nucleus ruber at the level of brain stem, and bilaterally in the thalamic nuclei and lentiform nucleus at the level of basal ganglia, which suggested accumulation of iron (Figure 3, 4). No additional neurologic symptoms were found at follow-up. Genetic analysis could not be ordered because of the economic problems of the patient. Desferrioxamine treatment was initiated after consulting the department of metabolism disorders and no additional neurologic symptoms or cognitive decline were detected at follow-up.

CP, an alpha 2 glycoprotein, carries $95 \%$ of the copper in plasma and is synthesized by hepatocytes. It allows transportation of iron by its ferroxidase enzyme activity, which converts $\mathrm{Fe}^{+2}$ to $\mathrm{Fe}^{+3}$ and leads to the binding of iron to transferrin. Thus, iron is mobilized from its tissue depots $(1,2,3,4,5)$. Aceruloplasminemia (AP) is an autosomal recessive inherited disease caused by mutations in the $\mathrm{CP}$ gene. Mutations in the $\mathrm{CP}$ gene cause a decrease in ferroxidase activity, which leads to an accumulation of iron in the pancreas, liver, and cerebrum, and causes progressive neurodegeneration in the basal ganglia $(1,2)$. It was described for the first time in Japan in 1987 by Miyajima (1) on a patient with blepharospasm, diabetes mellitus, and retinal degeneration $(4,5)$. It affects middle-aged people. Its incidence is very low; 1 in $2,000,000$ patients without consanguinity $(1,3,4)$. In disorders of iron metabolism, reactive oxygen radicals such as $\mathrm{AP}$, a derivate of iron, facilitate cell damage and cause synaptolysis, apoptosis, and

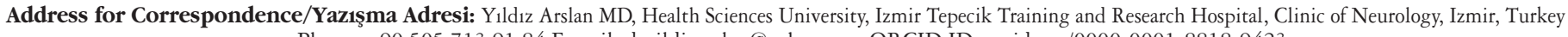
Phone: +90 5057139184 E-mail: dryildizarslan@yahoo.com ORCID ID: orcid.org/0000-0001-8818-9423

Received/Geliş Tarihi: 05.12.2016 Accepted/Kabul Tarihi: 19.02.2017

${ }^{\circ}$ Copyright 2017 by Turkish Neurological Society

Turkish Journal of Neurology published by Galenos Publishing House. 

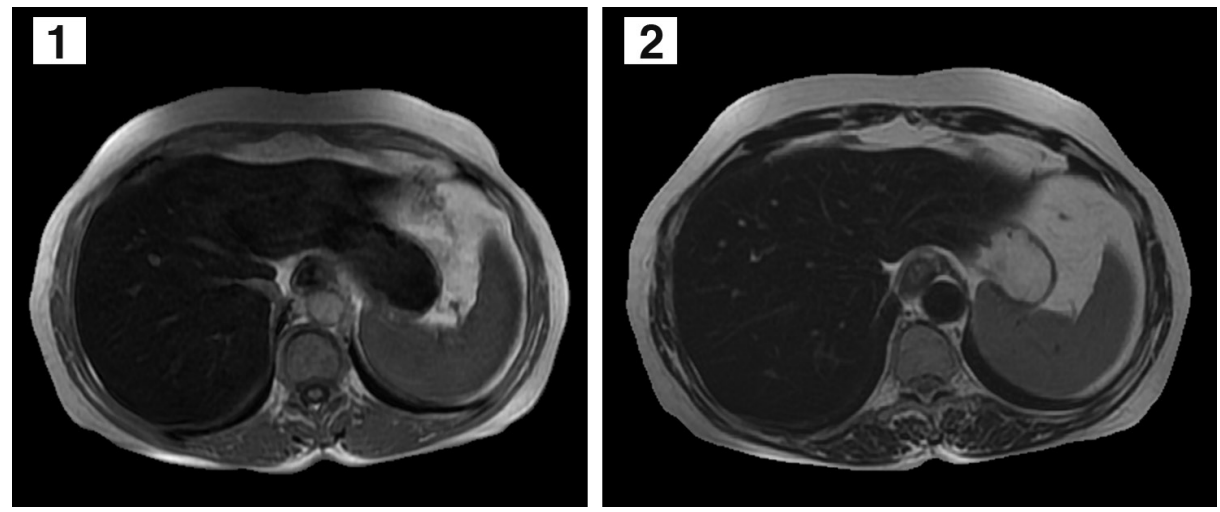

Figure 1, 2. Abdominal magnetic resonance imaging shows decrease in the signal of liver parenchyma due to accumulation of metal.
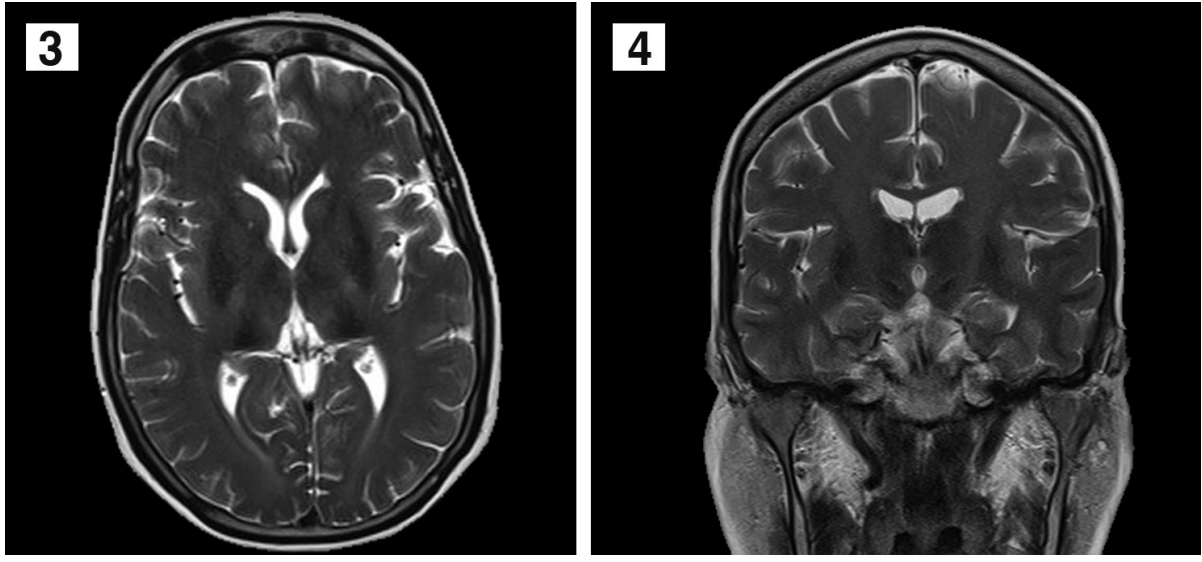

Figure 3, 4. Brain magnetic resonance imaging shows bilateral signal changes in the white matter of the cerebellum, nucleus ruber at the level of brain stem, and bilaterally in the thalamic nuclei and lentiform nucleus at the level of basal ganglia, which suggests accumulation of iron.

necrosis (1). The accumulation of iron especially affects glial cells in the basal ganglia and thalamus. Iron accumulates in astrocytes and microglial cells more than neurons in these regions and causes cell death (2,3). The classic triad of AP includes diabetes mellitus, retinal degeneration, and adult-onset neurologic symptoms $(2,5)$. Early diagnosis of the disease with clinical symptoms is difficult because the phenotype of the disease is heterogeneous (2). The most frequent $(68 \%)$ neurologic findings of the disease are as follows; ataxia, cognitive dysfunction, involuntary movements, dysarthria, dystonia and parkinsonism. Cognitive dysfunction constitutes $60 \%$ of neurologic findings (1). Laboratory findings are anemia $(80 \%)$, high serum level of ferritin despite low serum levels of iron, and very low or undetectable serum levels of CP and copper. Liver biopsy shows severe accumulation of iron $(1,4,5)$.

AP is a fatal and slowly progressive, neurodegenerative disease. Early diagnosis and initiation of treatment are very important. Patients benefit from iron chelation therapy including desferrioxamine and oral zinc sulphate $(3,5)$.

Ethics

Informed Consent: A consent form was completed by the patient.

Peer-review: Internally peer-reviewed.

\section{Authorship Contributions}

Surgical and Medical Practices: Y.A., U.Ş., Concept: Y.A., U.Ş., Y.Z., Design: Y.A., Y.Z., Data Collection or Processing: Y.A., A.Ş., Analysis or Interpretation: Y.A., U.Ş., Literature Search: Y.A., U.Ş., A.S., Writing: Y.A.

Conflict of Interest: No conflict of interest was declared by the authors.

Financial Disclosure: The authors declared that this study received no financial support.

\section{References}

1. Miyajima H. Aceruloplasminemia. Neuropathology 2015;35:83-90.

2. Ogimoto M, Anzai K, Takenoshita H, Kogawa K, Akehi Y, Yoshida R, Nakano M, Yoshida K, Ono J. Criteria for early identification of aceruloplasminemia. Intern Med 2011;50:1415-1418.

3. Suzuki Y, Yoshida K, Aburakawa Y, Kuroda K, Kimura T, Terada T, Kono S, Miyajima H, Yahara O. Effectiveness of oral iron chelator treatment with deferasirox in an aceruloplasminemia patient with a novel ceruloplasmin gene mutation. Intern Med 2013;52:1527-1530.

4. Roberti Mdo R, Borges Filho HM, Gonçalves CH, Lima FL. Aceruloplasminemia: a rare disease-diagnosis and treatment of two cases. Rev Bras Hematol Hemoter. 2011;33:389-392.

5. Kono S, Miyajimi H. Molecular and pathological basis of aceruloplasminemia. Biol Res 2006;39:15-23. 